Vol. 2, No. 1, pp. 24-31, 2021

\section{The Effect of Stimulus Policies and Risk-Based Capital Levels on Solvency at PT. Indonesian Takaful using Sharia Principles during the Majeur Force Period (Covid-19 Pandemic) in Indonesia}

\author{
Nano Suyatna* \\ Ma'soem University, Jatinangor, 45363, Jawa Barat, Indonesia
}

Corresponding author email: nanosuyatna.ns@gmail.com

\begin{abstract}
The Covid -19 pandemic is a massive disaster, impacting various sectors of the economy including the Islamic principle insurance sector. The government through the Financial Services Authority (OJK) in dealing with these problems has issued a stimulus policy so that the Islamic principle insurance sector is still able to maintain the level of solvency and risk based capital is maintained. The purpose of this study is to determine the influence of the Stimulus Policy and the level of Risk Based Capital on the level of solvency of sharia-based insurance PT. Tafakul Indonesia during the Covid-19 Pandemic. The method used is descriptive method with a simple statistical approach. The results show: 1 . There is a positive influence of the Stimulus Policy on the Solvency Level of PT. Tafakul Indonesia, 2. There is a positive influence on the Level of Risk Based Capital on the Solvency Level of PT. Tafakul Indonesia, 3. There is an influence of the Stimulus Policy and Level of Risk Based Capital on Simultaneous level of solvency in PT. Tafakul Indonesia. From the research results, it can be concluded that the Stimulus Policy and Risk Based Capital Level that has been set by the regulator is right on target. The OJK policy is very precise in maintaining the survival of the insurance company PT. Takaful Indonesia in particular, so that during the Covid 19 Pandemic it still existed.
\end{abstract}

Keywords: Stimulus Policy, Level of Risk Based Capital, Level of Solvency, Covid-19 Pandemic

\section{Introduction}

In addition to negative impact caused by this outbreak it turns out that there are the bright sides. Firstly, the increase of the purchasing power of local goods because the government has banned imported goods during this outbreak. Secondly, the air pollution has decreased due to the lack of vehicles caused by social distancing. The Financial Services Authority (OJK) issued a further stimulus policy in the non-bank financial industry sector by providing adjustments to the technical implementation of marketing for Investment-Related Insurance Products (PAYDI). The policy was issued as an effort by the OJK to maintain the performance and stability of the insurance industry amidst the economic downturn due to the Covid-19 pandemic (Otoritas Jasa Keuangan, 2020).According to Riswinandi, as stated in the Circular Letter to LKM (Micro Financial Institutions) management and directors, the OJK policy for LKMs and LKM's debtors is aimed at reducing the burden on low-income people and micro-scale businesses in paying obligations to LKM and maintaining the sustainability of LKM's performance. The policy for LKMs consists of: a. Extension of 10 working days from the deadline for submission of 4 monthly financial statements and evidence of financial statement announcement for the period April 2020, b. Providing restructuring for debtors affected by the spread of Covid-19, c. The quality of loans or financing for debtors affected by the spread of the restructured Covid-19 is determined to be current since the restructuring was carried out, $d$. The implementation of restructuring for debtors affected by Covid-19 is valid for 6 months (Otoritas Jasa Keuangan, 29 May 2020).The Financial Services Authority (OJK) issued a Circular Letter (SE) regulating risk-based minimum investment and capital assessment (MMBR) for insurance and reinsurance companies and pension funds. The regulation is targeted to provide a stimulus for industry amid a weakening economy. The three circular letters have been in effect since August 31, 2015. The first circular, namely OJK Circular Letter Number 24 of 2015 concerning Debt Securities Investment Assessment and Risk-Based Minimum Capital Adjustment for Insurance Companies and Reinsurance Companies. Second, OJK Circular Letter Number 25 of 2015 concerning Assessment of Sharia Securities Investment and 
Calculation of Funds to Anticipate the Risk of Failure in the Management of Wealth and or Liabilities of Sharia Insurance Coanies and Sharia Reinsurance Companies. In addition, the authorities issued OJK Circular Letter Number 26 of 2015 concerning Investment Assessment of Securities for Pension Funds. Edi Setiadi explained, with this regulation, insurance companies can evaluate debt securities using a reduced cost (amortization). In October 2015, due to the downturn in financial markets, OJK released SE number 24 / SEOJK 05/2015 concerning the assessment of debt securities investment and risk-based minimum capital adjustments for insurance companies and reinsurance companies. OJK lowered the basis of the solvency level of insurance and reinsurance companies.

Firdaus Djaelani stated that not many companies have taken advantage of the regulation until now. It was true that at that time the value of the capital market had fallen, but many of them were still holding back, the loss was not realized. Most general insurance companies in Indonesia, he said, already have an RBC of above 120\%, the lower limit of regulatory regulations. Life insurance company RBC, he said, is even safer at more than 500\%.The Indonesian General Insurance Association (AAUI) suggested that even if the MMBR regulation was revoked, it should be done gradually. The current provision is that the MMBR component is at least $50 \%$. So if you want to return to $100 \%$ gradually starting from $60 \%$ (Financial Services Authority, 2015). In addition, insurance companies can make adjustments to the amount of MMBR calculated in the calculation of a solvency level of at least 50 percent. Insurance companies and reinsurance companies can make adjustments to the MMBR until the solvency level reaches a maximum of 120 percent. Meanwhile, for sharia insurance companies and sharia reinsurance companies, the solvency level of tabarru 'funds (the collection of funds originating from participant contributions) reaches a maximum of 30 percent. As a regulation, insurance companies must have a solvency rate of 120 percent. And relaxation of regulations is issued by the authorities because the current economic conditions in Indonesia are affected by global conditions that have an impact on the money market and capital market. The impact of the weakening in the market has hit the financial industry, particularly insurance companies and pension funds. This is because the two industries invest in the capital market.

From the existing indicators, the researcher measures how much is the effectof the Stimulus Policy and Risk Based Capital Level on the Solvency Level of the Force Majeure Sharia Principal Insurance Company (Pandemic Covid-19) in Indonesia, so that the sharia insurance company is able to survive

Want to find out how much influence the Stimulus Policy has on the level of solvency of the Islamic principle insurance company sector (PT. Takaful Indonesia), and want to know how much influence the Risk-Based Capital Level has on the level of solvency in the Islamic principle insurance company sector (PT. Takaful Indonesia), wants to know how much the magnitude of the influence of the Stimulus Policy and Risk-Based Capital Levels on the level of Solvency in the Islamic principle insurance company sector (PT. Takaful Indonesia) simultaneously.

\section{Background Theory}

This research is initiated by the results of previous studies including:

Lee et al. (2019) after the introduction of RBCT, FTO is facing with a more challenging operating environment to maintain the capital requirement and market share. The higher operating costs may arise in meeting the RBCT requirements. Thus, they are encouraged to be more efficient in enhancing internal controls to maintain the capital requirement and market share in the competitive Takaful market (Malaysian Takaful Dynamic, 2015). There by, the RBCT framework has pushed the Takaful operators in Malaysia to improve their efficiency and remain competitive in orderto protect the interest of public. Ahmad and Prasetyo (2018) The premium income, underwriting, risk-based capital have effect to company profitability while liquidity and growth have no effect. Dewi and Mahfudz (2016) The result indicated that the variable of incurred loss ratio, liquidity (liabilities to liquid asset) ratio has positive and significant effect on the occurrence of financial distress. Size variable has a negative and significant effect on the occurrence of financial distress, while change in surplus ratio, premium growth ratio and risk based capital ratio have no significant effect on the insurance company's financial distress.

Nasution et al. (2019) Based on the analysis result and discussion above, it can be concluded that there are differences in RBC of Islamic insurance companies in Indonesia and Malaysia based on the Mann-Whitney test. Furthermore, for Islamic insurance companies both in Indonesia and Malaysia, RBC, liquidity, and investment balance ratio have a significant effect on the profitability of Islamic insurance companies in Indonesia. Meanwhile, investment return does not have a significant effect on profitability for Indonesian Islamic insurance companies but not for Malaysian Islamic insurance companies.

Based on the Minister of Finance Regulation No.11 / PMK.010 / 2011 concerning Financial Health in Insurance Business and Reinsurance Business with Sharia Principles. In these regulations, sharia general insurance companies must carry out and maintain financial health in terms of tabarru' fund levels according to the minimum required solvency level of the funds required to anticipate the risk of loss that may arise as a result of deviation in the management of assets and / liabilities. To meet these requirements the insurance industry must have a strategy to maintain and increase the solvency of the tabarru'. With the fulfillment of the minimum solvency, the insurance 
company will get the trust of the participants that the tabarru' fund is able to meet all the risks of possible losses to participants.

Tarsono et al. (2020) Risk Based Capital has a negative effect on the company's financial performance which shows that the ability of insurance companies in managing their wealth and obligations in accordance with the level of risk faced by the company. The higher the value of RBC, the risk that the company also gets higher so that it can affect the decline in corporate profits, which means that if profits decline the financial performance of life insurance companies will decline.

Utami and Khoiruddin (2016), advice given to investors who are going to buy insurance products does not need to pay attention to the liquidity ratio, own retention ratio and company size in assessing the solvency level of Islamic life insurance companies because these three ratios have no effect on the level of solvency. The suggestion for the company is to maximize the premium in order to cover the company's expenses because the load ratio affects the level of solvency.

Ambarwati and Hasib (2018) presented the panel data method with the Fixed Effect Model (FEM) approach, a sample of 17 general and sharia life insurance companies in Indonesia for the period 2012 - 2016. The results show that partially, company size affects solvency and simultaneously all variables free effect on solvency. It is necessary to add other variables that can affect solvency.

Kirmizi and Agus (2011), path analysis method, sample of 61 general insurance companies from 2000 to 2007. The results showed that capital and asset growth had no effect on Risk Base Capital (RBC). Şumandea-Simionescu (2015) studied on the Romanian insurance market between 2008 and 2012, we sought to identify, on the foundation of the work done by our academic predecessors, the varying and noteworthy influences of insurance companies solvency. Through the undertaken empirical analysis of Romanian insurance companies, in regard to the factors that will influence the degree of exposure of the solvency of insurance companies, we have concluded the following: Our initial hypothesis, that diversification through reinsurance reduces the insolvency risk, was completely confirmed, Liquidity issues of the insurance company can be observed where the insurers invests heavily in fixed assets and/or are unable to control their debtor pool, which could affect their ability to fulfil their obligations to other third parties, On the Romanian insurance market, an increase of the size of the company will increases the risk of insolvency of the insurer, An increase of the total debt to equity capital ratio is registered in case of an increase in the affiliation percentage of the Romanian insurance companies, A high ratio of total gross damage to total premiums causes an increase of the debt to equity capital ratio and an increase of the solvency risk.

Treatment of Insurance Companies in response to countercyclical policies on the Impact of the Spread of Covid-19. The Financial Services Authority or OJK issued a countercyclical policy for non-bank financial service institutions through letter number S-11 / D.05 / 2020 concerning the Countercyclical Policy on the Impact of the Spread of Coronavirus Disease 2019 (Covid-19) for Insurance Companies on March 30, 2020. The issuance of the letter was addressed positively by each financial service actor. On the other hand, financial service actors must face "pressure" from their customers who ask for relaxation of postponement of obligations because the insured is currently experiencing cash flow. There are two things that need to be addressed in the OJK policy, first related to relaxation in calculating the level of solvency. Limitation on Permitted Assets (AYD) in the form of non-investment in direct closing premium claims including coinsurance premium receivables, reinsurance premium claims, extended from 2 (two) months to 4 (four) months. Recognition in the AYD is for bills with maturities above January 2020, that the insurance company decides to provide concessions to its customers while still considering the prudent principles in its implementation.

This allows for an incorrect understanding, where all insurance premium bills will be given an extension of the payment due date. OJK has never given directions to insurance companies to extend the maturity of insurance premium payments. What is provided by the OJK in the context of relaxation is the convenience for insurance companies to still be able to recognize bills that are past due more than 2 months as AYD in calculating the level of solvency. The decision not to cancel an insurance policy, of course, returns to the considerations and decisions of each insurance company. For this reason, if the insurance company does decide to provide such discretion, AAUI calls on several things: First, the discretion is given to those who are truly affected and do not use this discretionary mechanism for the ongoing practice of switching coverage. If this applies to all the insured, what will happen is a big loss for the financial services sector. Second, ensuring that the ultimate beneficiary who receives the benefits of the discretion is the insured and not the intermerdiaries, so that any extension discretion given must only be made with a direct written request from the insured. Third, to remind in writing of laws and regulations to intermediaries that the act of withholding paid premiums is an act that is a criminal domain and can be followed up legally. Fourth, discretion related to a facultative reinsurance program or coinsurance is carried out with the mutual consent of the Insurers, Reinsurers and Coinsurers.

Regarding the relaxation (stimulus), insurance companies must always take into account the company's cash-flow capabilities and also the obligations to employees and other stakeholders while maintaining the interests of 
shareholders. The second thing that needs to be paid attention to in the OJK policy is the relationship between the general insurance industry and the financing industry related to the loan restructuring option in financing companies by extending the loan tenor, where this extension of course requires insurance protection with an additional new tenor for the insured financing assets. What needs to be considered is that in every closure of long-term insurance coverage, the risks that exist will immediately lead to obligations which have been fulfilled in several applicable laws and regulations. Thus, just as a finance company cannot provide financing loans without cash, due to existing regulations and obligations, insurance companies cannot provide protection without a premium.

The financial health of Islamic insurance companies is one of the components in assessing and monitoring company performance. Islamic insurance companies are obliged to maintain financial health because they are responsible for financial management obtained from insurance participants. In the financial management of Islamic principles insurance companies require a set of systems and proper procedures, so that financial information is used as a basis for decision making, reliable financial information.

Therefore, in this study using the financial statements of each company to measure the level of solvency and cash flow of Islamic insurance companies that may be influenced by the variables of Stimulus Policy and Risk Base Capital Level.

\section{Hypothesis}

In this study, the researcher has several hypotheses as follows:

\subsection{How big is the relationship between Stimulus Policy and Solvency Level at PT. Force Majeure (Pandemic Covid-19) Period Takaful Insurance in Indonesia?}

The Financial Services Authority (OJK) has issued OJK Regulation Number 11 / POJK.03 / 2020 concerning National Economic Stimulus as a Countercyclical Policy Against the Impact of Coronavirus Disease Spread. However, banks must be careful so as not to cause moral hazard problems (Ryan Kiryanto, 19 August 2020). The stimulus through POJK is quite effective in helping sharia insurance companies and clients in the real sector to revive their business. The goal is to return to normal business operations, return to smooth cash flow, and increase solvency and stable profitability. H1: The stimulus policy affects the level of solvency in sharia life insurance companies during the Force Majeur period (Covid-19 Pandemic) in Indonesia.

\subsection{How big is the relationship between the Level of Risk Based Capital and the Level of Solvency at PT. Takaful Insurance during the Force Majeure Period (Pandemic Covid-19) in Indonesia?}

The trust of an insurance company to its customers is based on the financial health factor of the insurance company in particular to be able to provide compensation for losses suffered by its customers, and in general an insurance company is believed to be able to meet all needs. liability through evidence that the company's financial condition of the insurance company is healthy enough to run its business by having assets and strong capital that exceeds the amount of liabilities it has. Risk Based Capital is a method of measuring the limit level of solvency required by law in measuring the level of financial soundness of insurance companies to ensure fulfillment of Insurance and Reinsurance obligations by knowing the size of the company's capital requirements according to the level of risk faced by the company in managing its assets and liabilities. At all times, the company is required to meet a solvency level of at least $100 \%$ of the minimum risk-based capital. Every year the company is required to set a target level of solvency. (2) The target level of solvency as referred to in paragraph (2) is at least $120 \%$ (one hundred and twenty percent) of the risk-based minimum capital. The Minister may order the Company to increase the Solvency level target as referred to in paragraph (3) by considering the risks that may arise from the planned change in strategy and / or development of the Company's business. In the event that the Company is unable to fulfill the order to increase the Solvency Level target as referred to in paragraph (4), the Company is prohibited from implementing plans for changing its strategy and / or business development (Ministry of Finance, 53 / PMK.010 / 2012, April 3, 2012. H2: Level Risk Based Capital affects the level of solvency of PT. Tafakul Insurance for the Force Majeure (Pandemic Covid-19) period in Indonesia.

\section{Methods}

The method used by the author in this study is inferential causality with data analysis techniques using multiple regression. A method that describes the actual situation to obtain data which is then processed, analyzed and further processed based on the theory that has been studied so that a data conclusion can be drawn. 
This research was conducted on a sharia-based insurance company in Indonesia as a population, which consists of 3 general sharia insurance holding companies, 18 general sharia insurance unit companies and 3 general sharia reinsurance unit companies.

The sample taken is PT. Tafakul Insurance in Indonesia, because it is an independently unaffiliated sharia insurance company and more research data availability.

The variables studied were Stimulus Policy as the independent variable, Risk Based Capital (RBC) as the independent variable, and the level of solvency as the dependent variable. The research period is used on a quarterly basis starting from the first quarter of 2017 to the third quarter of 2020, 15 financial reporting periods.

This multiple regression model is used to find predictions using the Multiple Linear Regression equation with the following steps:

1. Normality Test

Normal Distribution

Skewness $=0.303 / 0.687=0.441$

Kurtosis $=0.504 / 1.334=0.3778$

Both must be between -2 and 2 , which is a normal distribution

2. Autocorrelation Test

DWcount $=1.511$

$\mathrm{DL}=0.6972$

$\mathrm{DU}=1.6413$

$4-\mathrm{DL}=4-0.6972=3.3028$

$4-\mathrm{DU}=4-1.6413=2.3587$

$\mathrm{N}=10$

$\mathrm{K}=2$

The calculated DW value of 1.511 is greater than 0.6972 and less than 1.6413 , which means that there is no autocorrelation in the area.

So it can be concluded that the linear regression model does not occur autocorrelation.

\section{Partial t test}

Partially, RBC has an influence on the Solvency Level of Sig. $0.04<0.05$

Partially, the Stimulus Policy has an influence on the Solvency Level of Sig. $0.003<0.05$.

Finding t table:

t table: $(\mathrm{a} / 2: \mathrm{n}-\mathrm{k}-1)$

t table: $(0.05 / 2: 10-2-1) \square 1=$ independent variable

$\mathrm{t}$ table: $(0,025: 7) \square 7$ resedual in Anova

t table: 2.36462

t count:

Realized RBC $=2.522>\mathrm{t}$ table: 2.36462 , Ho is accepted, it affects the level of solvency

OJK stimulus $=4.447>\mathrm{t}$ table: 2.36462 , Ho is accepted, it affects the level of solvency

4. Simultaneous F Test

Influence of stimulus, RBC due to R2 0.893 or $89.3 \%$, the remaining $100-89.3=9.7 \%$, R2> $50 \%$ and $<95 \%$ to $98 \%$.. so there is a simultaneous relationship. Hypothesis accepted.

$\mathrm{Sig},<0.05$, the hypothesis is accepted, the hypothesis has a simultaneous effect. The hypothesis is accepted.

Or F count $>$ F table, accepted. There were simultaneous effects. This is Sig. 0.00

See Table F

$\mathrm{Dv}=\mathrm{ftabel}=(\mathrm{k}: \mathrm{n}-\mathrm{k})$

$\mathrm{k}=2, \mathrm{n}=10$

f-table $=(2: 10-2)$

$=(2: 8)$

f-table $=4.46<\mathrm{f}$ count $=29.277$, it is concluded that the hypothesis is accepted simultaneously.

5. The exact multiple regression equation, because it has 2 independent variables and 1 dependent variable is as follows:

$\mathrm{a}=$ constant

$$
\hat{Y}=a+b X^{1}+b X^{2}+e
$$

$\mathrm{b}=$ regression coefficient

$\mathrm{Y}=$ Level of Solvency

$\mathrm{X} 1=$ Stimulus Policy 


$$
\begin{aligned}
& \mathrm{X} 2=\text { Risk Based Capital } \\
& \mathrm{e}=\text { errors }
\end{aligned}
$$

\section{Results and Discussion}

Togar Pasaribu, the Indonesian Life Insurance Association (AAJI) admitted that he had discussed with the OJK regarding insurance policy tools. Togar Pasaribu explained that the policy tool was to loosen up the MMBR calculation. MMBR is calculating and assessing Risk Based Capital (RBC). It is hoped that with relaxation, the RBC will not be disturbed because of the low RBC factor at that time and in addition, if there are still companies that have RBC below 120 percent then there must be additional capital. Togar asked that the regulations be not too strict, the condition was that there must be stimulus assistance from the government.

The authority has prepared three countercyclical policies for the insurance industry (Financial Services Authority, Letter No: S-11 / D.05 / 2020, 2019.

First, an extension of the deadline for submitting periodic company financial reports to the OJK. Insurance companies get relaxation time to submit financial reports from 14 working days to two months.

Second, OJK regulates that the implementation of fit and proper tests for insurance companies can be done via video conference.

Third, calculating the solvency level of insurance and reinsurance companies, both conventional and sharia. Authorities allow the calculation of investment assets based on the amortized cost of a number of assets. In addition, the authority also allows restrictions on assets in the form of non-investment in direct closing premium claims, including coinsurance premium claims, reinsurance, tabarrru 'fees, and direct closing costs, as well as claims on coinsurance, reinsurance contributions and claims for reinsurance premiums. The restrictions were extended, from two months to four months after maturity. This applies on condition that the company provides an extension of the deadline to policyholders for four months and only applies to premium or contribution bills that are effective from February 2020.

Riswinandi explained, OJK urges insurance companies to implement countercyclical policies by taking into account the principles of prudence, risk management and good corporate governance. That in the context of making policies related to the impact of the spread of Covid-19, OJK may request additional data and information from insurance companies outside of routine reporting, as regulated in laws and regulations.

Risiwnandi explained, the countercyclical policy as referred to in number 2 (regarding restrictions on assets allowed in the form of non-investment at direct closing premiums) came into effect on March 30, 2020 (Wibi Pangestu Pratama, Bisnis.com, August 13), 2020).

Achmad Sudiyar Dalimunthe, the Indonesian General Insurance Association, explained that the easing is intended so that insurance companies can survive by maintaining their level of solvency in the midst of worrisome market conditions due to the spread of Covid-19. The potential that can arise is the late payment of insurance premiums, and it can have an impact on the automatic cancellation of the policy because the premium payment deadline has passed. This will be detrimental to the insured, especially when making a claim. The amount of the company's insurance premium receivables will increase, while the arrangement of insurance premium receivables if it exceeds two months cannot be considered as Allowable Asset (AYD), thus disturbing the level of solvency. By relaxing the extension of the premium receivable life from two months to four months, it can still be included as AYD and does not interfere with the level of solvency (AAUI, 13 August 2020).

Wimboh Santoso, The Covid-19 Pandemic has really hit the commercial insurance industry business. Data from the Financial Services Authority (OJK) noted that the life and general insurance industry collected premiums of Rp 17.5 trillion or contracted $7.51 \%$ yoy. The growth trend for insurance premiums has decreased, especially for life insurance. Life insurance premiums were corrected by minus $13.8 \%$ yoy, where in December 2019 it was only minus $0.38 \%$. General insurance trend grew at a low level of $3.65 \%$ yoy, where last December grew $15.65 \%$ yoy. This was corrected in the insurance industry due to Covid-19.

In the first quarter of 2020, the sharia insurance industry experienced a decline in the value of assets and investment by respectively $9.52 \%$ (qtq) and $11.83 \%$ (qtq) to Rp 41.12 trillion and Rp 35.13 trillion. On a year-on-year basis, the gross contribution in the first quarter of 2020 increased $4.30 \%$ to $\mathrm{Rp} 4.01$ trillion, and gross claims increased by $45.92 \%$ to $\mathrm{Rp} 3.12$ trillion. Management of a sharia insurance company is carried out in full and sharia units. Until the end of the reporting period there were 63 companies consisting of 12 full fledge sharia insurance companies, one full fledge sharia reinsurance company, 47 insurance companies that have sharia units and three reinsurance companies that have sharia units (OJK, Quarterly Report I-2020, 155). The Financial Services Authority (OJK) noted that until May 2020 the gross contribution (premium) of Islamic life insurance reached Rp 5.31 billion. Meanwhile, in the same period last year it reached Rp. 5.15 billion, an increase of 0.16 billion.

The results of the research that the period used on a quarterly basis from quarter I-2018 to quarter II- 2020 are as follows; 1. There was a decrease in Risk Based Capital from the fourth quarter - 2019 to the first quarter 2020 by $4 \%$ 
and from the fourth quarter - the 2019 period to the second quarter 2020 period by $2 \%$. This shows that the decline in Risk Based Capital is getting smaller, the financial condition of Islamic insurance companies shows an upward graph in a positive direction. 2. There was an increase in the Solvency Ratio from quarter IV - 2019 to quarter I-2020 by 3\% and from quarter IV - 2019 to quarter II-2020 by 5\%. This shows that the increase in the Solvency Ratio is getting better, the financial condition of the Islamic principle insurance company shows that the Solvency Ratio graph increases in a positive direction.

The results of the study by taking a sample of PT. Takaful Indonesia Insurance in analyzing Stimulus Policy, Risk Based Capital and Solvency Levels as follows:

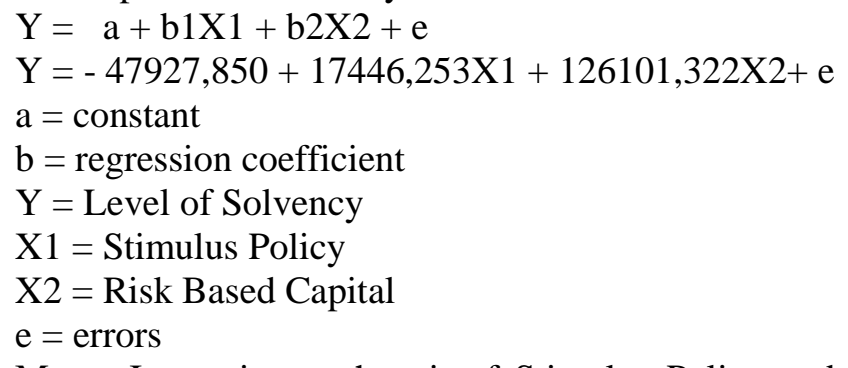

Mean: Increasing each unit of Stimulus Policy and Risk Based Capital will have an impact on increasing the Solvency Level at PT. Indonesian Takaful Insurance.

\section{Conclussion}

The results showed that there was an influence; 1 . There is a strong positive influence of the Stimulus Policy (Pandemic Covid-19) on the Solvency Level of PT. Asuransi Tafakul Indonesia, 2. There is a strong positive influence on the Level of Risk Based Capital on the Solvency Level of PT. Asuransi Tafakul Indonesia, 3. There is a positive influence on the Stimulus Policy and the Level of Risk Based Capital on the Level of Solvency at PT. Simultaneous Indonesian Tafakul Insurance. The OJK policy is very precise in maintaining the survival of the insurance company PT. Takaful Indonesia in particular, so that during the Covid 19 Pandemic it still existed.

\section{References}

Ahmad, G. N., \& Prasetyo, R. P. (2018). Profitability analysis of non-life insurance: Case in Indonesia stock exchange. KnE Social Sciences, 335-350.

Ambarwati, S., \& Hasib, F. F. (2018). Pengaruh Ukuran Perusahaan, Hasil Investasi, Dan Profitabilitas Terhadap Solvabilitas Asuransi Syariah Di Indonesia Periode 2012-2016. Jurnal Ekonomi dan Bisnis Islam (JEBIS), 4(2), 91-102.

Dewi, T. T. C., \& Mahfudz, M. (2016). Effect of Change in Surplus Ratio, Incurred Loss Ratio, Liquidity Ratio, Premium Growth Ratio, Firm Size and Risk Based Capital to Predict The Posibilities of Financial Distress: The Case of Indonesian NonLife Insurance Listed in Indonesia Insurance Dir. Diponegoro Journal of Management, 5(3), 627-642.

Keuangan, O. J. ( 2020). Peraturan Otoritas Jasa Keuangan Republik Indonesia Nomor : 14/POJK.05/2020 Tentang Kebijakan Countercyclical Dampak Penyebaran Coronavirus Disease 2019 bagi Lembaga Keuangan Non Bank. Jakarta: Otoritas Jasa Keuangan.

Keuangan, O. J. (2015). SE OJK Nomor 24/SEOJK.05/2015 tentang Pedoman Perhitungan Jumlah Modal Minimum Berbasis Risiko bagi Perusahaan Asuransi dan Perusahaan Reasuransi. Jakarta: Otoritas Jasa Keuangan .

Keuangan, O. J. (2016). Surat Edaran OJK No. 21 /SEOJK.05/2016 tentang Pencabutan Surat Edaran Otoritas Jasa Keuangan No: 24/SEOJK.05/2015 Tentang Penilaian Investasi Surat Utang dan Penyesuaian Modal Minimum Berbasis Risiko bagi Perusahaan Asuransi dan Perusa. Jakarta: Otoritas Jasa Keuangan.

Keuangan, O. J. (2017). No. 25 /SEOJK.05/2017, Pedoman Perhitungan Jumlah Dana Tabarru' dan Dana Tanahud Minimum Berbasis risiko dan Modal Minimum Berbasis Risiko bagi Perusahaan bagi Perusahaan Asuransi dan Perusahaan Reasuransi dengan Prinsip Syariah. Jakarta: Otoritas Jasa Keuangan.

Keuangan, O. J. (2017). Surat Edaran No.25/SEOJK.05/2017, Tentang Pedoman Perhitungan Jumlah Dana Tabarru'dan Dana Tanahud Minimum Berbasis Risiko dan Perusahaan Reasuransi dengan Prinsip Syariah. Jakarta: Otoritas Jasa Keuangan. 
Keuangan, O. J. (2019). , Frequently Asked Questions (FAQ) Peraturan Otoritas Jasa Keuangan Nomor 14/POJK.05/2020 tentang Kebijakan Countercyclical Dampak Penyebaran Coronavirus Disease 2019 Bagi Lembaga Jasa Keuangan Nonbank (POJK COVID-19 LJKNB), no.32. Jakarta: Otoritas Jasa Keuangan.

Keuangan, O. J. (2020). Laporan Triwulan I 2020. Jakarta: Otoritas Jasa Keuangan.

Keuangan, O. J. (2020). SP 39/DHMS/OJK/V/2020 , Siaran Pers Kebijakan Stimulus Lanjutan bagi Industri Keuangan Non Bank, Jakarta, 29 Mei 2020, hal. 2. Jakarta: Otoritas Jasa Keuangan.

Keuangan, O. J. (2020). Surat Edaran No: S-11/D.05/2020 tentang Kebijakan Countercyclical Dampak Penyebaran Coronavirus Disease 2019 (Covid-19) bagi Perusahaan Perasuransian. Jakarta: Otoritas Jasa Keuangan.

Kirmizi and Agus, S. S. (2012). Pengaruh pertumbuhan modal dan aset terhadap Rasio Risk Based Capital (RBC), pertumbuhan premi neto dan profitabilitas perusahaan asuransi umum di Indonesia. PEKBIS (Jurnal Pendidikan Ekonomi Dan Bisnis), 3(1), 391-405.

Lee, H. S., Cheng, F. F., Nassir, A. M., \& Hisyam Ab Razak, N. (2019). Impacts Of Risk Based Capital Regulation in Malaysian Islamic Insurers (Takaful). Asian Academy of Management Journal of Accounting \& Finance, 15(1), 27-59.

Nasution, Z., Adiba, E. M., \& Abdulrahim, M. O. (2019). Comparison analysis of risk-based capital (RBC) performance and its effect on islamic insurance profitability in Indonesia and Malaysia. al-Uqud: Journal of Islamic Economics, 3(2), 149160

Tarsono, O., Ardheta, P. A., \& Amriyani, R. (2020, March). The Influence of Net Premium Growth, Claim Ratio and Risk-Based Capital on the Financial Performance of Life Insurance Companies. In Annual International Conference on Accounting Research (AICAR 2019) (pp. 65-68). Atlantis Press.

Şumandea-Simionescu, I. (2015). The Impact of the European Neutrality Rule on Romanian Directors' Duties in Hostile Takeovers-A Case Study of Romanian Companies Present on the Bucharest Stock Exchange. Procedia Economics and Finance, 32, 383-393.

Utami, E. P., \& Khoiruddin, M. (2016). Pengaruh rasio keuangan early warning system terhadap tingkat solvabilitas Perusahaan Asuransi Jiwa Syariah periode 2010-2013. Management Analysis Journal, 5(1), 1-12. 